\title{
Note on Sources
}

Since the Poles regained their independence in 1989, no issue in PolishSoviet relations has been more sensitive than the Katyń Forest Massacre. Until Solidarity's rise in the late seventies, "Katyń" was officially a nonword, an absolute taboo, in Poland. Even families of victims shunned association with it, knowing that careers could be harmed, if not destroyed, by its mere mention in public.

Katyń was excised almost completely from the media. In February 1977, a Polish censor defected to Sweden with seven hundred pages of censors' classified documents. They included instructions to ensure that Polish media followed the Great Soviet Encyclopedia's brief version of Katyń, attributing guilt to the Nazis. These documents also warned censors that the names of Katyn victims must not be published. The defecting censor later said, "That was the limit of what I could take." His own grandfather was among the dead.

In April 1987 the Communist parties of Poland and the Soviet Union agreed to a joint study of several sensitive issues that caused deep animosity between the countries. Solidarity called it the Campaign to Eliminate Blank Spots because a full explanation had long been lacking for most of the matters to be examined. The Katyń Forest massacre and the mass deportation of Poles from lands seized by the Soviets in 1939separate aspects of the same policy to eliminate the Polish elite-were not on the list. Authorities on both sides still considered these events too sensitive to address. Two years later, with democratic reforms about to sweep Eastern Europe, a spokesman for the Communist government of Poland was forced to admit that "everything indicates that the crime was committed by the Stalinist NKVD [secret police]." Then, on April 13, 1990, 


\section{xxii Note on Sources}

Gorbachev admitted Soviet responsibility for Katyń, but said little else about the matter. The Soviets would not provide a complete explanation; important aspects of the crime were left unclarified.

Up until then excisions, blank spots, and misrepresentations were a problem in every official account of the crime except one. The Polish government-in-exile diligently sought and reported all the facts it could discover-and it is noteworthy that these efforts contributed to that government's own destruction. In the crime's immediate aftermath, the Soviet Union provided several grotesque and twisted versions of what happened. Nazi Germany embellished the facts to exacerbate tensions between the Allies. Great Britain and the United States actively suppressed evidence to prevent Western opinion from turning against the Sovietsboth during the war and at Nuremberg, where a botched Soviet indictment of the Nazis for the Katyń murders was quietly dropped. Even the "neutral" investigation of Katyn undertaken by the U.S. Congress in 1951 and 1952 was tainted by the desire to use Katyn as anticommunist propaganda during the Korean War. To one degree or another, ulterior motives made the truth secondary in all these official sources, leaving the record not so much blank as blurred.

In 2007, Yale University Press published a landmark study, Katyn: A Crime Without Punishment. It was prepared by three prominent scholars who had access to and translated important records found in the Russian military archives. They are Anna M. Cienciala, a specialist in twentiethcentury Polish diplomatic history and a retired professor of history at the University of Kansas; Natalia Lebedeva, the leading Russian historian of Katyn and a researcher at the Russian Academy of Sciences; and Wojciech Materski, the leading Polish historian of Katyń and Russo-Polish relations, who is director of the Institute of Political Studies at the Polish Academy of Sciences. I have relied heavily on their work in updating this edition.

My most important sources remain to be individuals with a direct personal knowledge of Soviet efforts to eradicate the Polish elite. Even here inherent limits confront us: The trail has grown cold; memory often plays tricks; and reliable records are difficult to find. Still, such recollections provide indispensable insight. To those who lost husbands, sons, and fathers in the massacre and to those who were deported, the Soviet policy was not an abstraction; it is a central event of their lives. Only they can put the scope and barbarity of what happened in true perspective. Any motive they may have had to embellish their accounts so as to prove Soviet guilt has now been removed. Their accounts thus become more valuable than ever, particularly in view of Russian's reluctance to make full and complete disclosures on the subject. 
For these reasons I have favored personal recollections in the narrative that follows. It draws heavily on many hours of discussion with people who were directly affected by the policies to eradicate the Polish elite and the country as they knew it. I believe that their revelations help explain why Katyń has become such a powerful symbol to the Poles, one that continues to block the path to better relations between the two countries. Readers can and should form their own judgments about what these personal accounts say about the terrible Katyń murders and their aftermath.

Finally, it is important to remember that these individual voices tell a story that could not be suppressed, no matter how strong the taboo, how deep the excisions, how subtle the ulterior motives. The durability of this story was predicted by Polish Ambassador Stanislaw Kot as far back as November 1, 1941, when he approached the Soviets with yet another inquiry about his country's missing officers. "People are not like steam," Kot fumed. "They cannot evaporate." In this case, truth, like matter, has proven to be indestructible. 
